\title{
SUGAR BIOSYNTHESIS IN VANILLA PLANTS AND PHALAENOPSIS SEEDLINGS AFTER APPLICATION OF FERTILIZERS
}

\section{BIOSINTESIS GULA DALAM TANAMAN PANILI DAN BIBIT PHALAENOPSIS SETELAH APLIKASI PEMUPUKAN}

\author{
I GEDE KETUT ADIPUTRA, \\ Department of Biology, Faculty of Natural Science, University of Hindu Indonesia Denpasar, Indonesia \\ *Corresponding author: dr_gede_adiputra@yahoo.co.id
}

Diterima 16 Juni 2016. Disetujui 10 Juli 2017

\begin{abstract}
In tropical country, vanilla encounters two main environmental conditions, wet and dry seasons. In the wet seasons when the amount of water available favours high growth rate, plants acquire more nutrients. However during dry seasons when water uptake via the root is limited and water loss from the shoot is increasing, vanilla will experience severe desiccations. In other cases, under condition of culture in bottle, phalaenopsis seedlings develop a very thin cuticle layers. These seedlings will experience a high rate of water loss when it is then transferred into ex vitro environmental conditions. Since mineral nutrient could decrease water potential in plants and enhanced by water loss, application of proper fertilizer into these vanilla plants and phalaenopsis seedling should not enhance the decreasing of water potential which could impair physiological mechanism. So, in order to ascertain nutrient requirement for these plants, two separate experiments were conducted. In the first experiment, vanilla plants grown in plantation were added 9.25, 1.1 and $4.6 \mathrm{~g} /$ plant Urea, TSP and KCL respectively. This experiment was repeated using different plants with application of fertilizer in higher doses; 18.5, 2.2 and 9.2 g/plant for Urea, TSP and $\mathrm{KCl}$, respectively. In order to examine the capacity of these plants to synthesize sugar, samples were then harvested in the period after fertilizer application, i.e. at day 0,11 and 24. In the second experiments, phalaenopsis seedlings were sprayed every 1-2 days with liquinox and rosasol-N fertilizer using factorial experimental design.. In order to examine the effect of the fertilizer on sugar biosynthesis, leaves of these plants were harvested at day 132. These experiments showed that addition of fertilizer into vanilla plants increased sugar content but addition of fertilizer into phalaenopsis seedling decreased sugar content. It is concluded that fertilizer applied into plants undergoing desiccation impair sugar biosynthesis.
\end{abstract}

Key words: Vanilla, phalaenopsis, fertilizers, sugar, growth, wet and dry seasons.

\section{INTISARI}

Di daerah tropis, tanaman panili menghadapi 2 musim yaitu musim hujan dan musim kering. Pada musim hujan, ketersediaan air sangat mendukung pertumbuhan sehingga tanaman memerlukan banyak unsur hara. Pada musim kering, penyerapan air yang terbatas oleh akar dan kehilangan air yang meningkat dari daun dapat mengakibatkan terjadinya desikasi. Pada kasus lain, bibit anggrek bulan dalam botol menghasilkan lapisan kutikula yang sangat tipis dan stomata yang tidak normal sehingga dapat mengalami desikasi yang sangat cepat setelah dipindahkan ke lingkungan ex vitro. Oleh karena pupuk anorganik dapat menurunkan potensial air, pemberian pupuk pada tanaman sebaiknya tidak merusak proses fisiologi akibat terlalu rendahnya potensial air. Untuk mengetahui keperluan nutrisi bagi tanaman panili dan anggrek bulan, maka dilakukan 2 percobaan secara terpisah. Pada percobaan pertama, tanaman panili yang ditumbuhkan di perkebunan diberikan pupuk Urea, TSP dan KCL masing-masing sebanyak 9.25, 1.1, dan $4.6 \mathrm{~g} /$ pohon. Percobaan ini diulangi pada tanaman panili lainnya menggunakan dosis yang lebih tinggi yaitu: 18.5, 2.2 dan 9.2 g/pohon. Pengambilan sampel dilakukan pada hari ke o, 11 dan 24 setelah pemberian pupuk. Pada percobaan kedua, bibit tanaman anggrek disemprot setiap 1-2 hari dengan larutan pupuk liquinok dan rosasol-N menggunakan desain percobaan faktorial. Daun anggrek kemudian disampel pada hari ke-132. Sampel kedua tanaman dianalisis untuk mengetahui pengaruh pemberian pupuk terhadap biosintesis gula. Penelitian ini menemukan bahwa pemberian pupuk pada tanaman panili dapat meningkatkan kadar gula tetapi pemberian pupuk pada bibit anggrek menurunkan kadar gula. Disimpulkan bahwa pemberian pupuk pada tanaman yang mengalami desikasi dapat merusak biosintesis gula.

Kata kunci: panili, anggrek bulan, pupuk, gula, pertumbuhan. 


\section{INTRODUCTION}

Epiphyte plants generally have much higher water use efficiency relative to soil-rooted plants (Reinert 1998). However, vanilla thrives well in humid tropical climates (Anandaraj et al. 2005). Hence, dry season is a critical period for vanilla to grow. In agricultural practice, watering at least twice a week is generally performed to maintain moisture in growth medium during the dry seasons (Hernandez 2011). Epiphyte plants are also subject to other environmental pressure similar to soil rooted plants, such as nutrient deficiency (Reinert 1998). However, albeit nutrient uptake from soil via the root system has widely been reported, nutrient requirements and possibly also mechanism of nutrient uptake in vanilla plants has not been clearly known. According to Zotz and Hietz (2001), it was remain argued that water and nutrient is the most important constrain for epiphytes plant to grow.

Similar to vanilla plants, nutrient requirement for phalaenopsis are also remaining unclear. According to Yin Tung Wang et al. (2007), misconception of proper fertilizer for phalaenopsis is often occurred where it is thought that phalaenopsis needs only little fertilizer. These authors revealed that phalaenopsis is a moderate feeder but only if this plant is grown on a right growth medium with sufficient watering. This implies that the rate of nutrient uptake is enhanced by increasing growth rate. If this is correct, uptake rate of newly applied fertilizer depend on the growth that using previously stored nutrient and this stored nutrient might not synthesized until environmental conditions favour the plant to initiate new growth. By contrast, newly imported nutrient will increased nutrient content in the plants irrespective of whether it is directly synthesize to support growth or stored as inorganic compounds. The mechanism of nutrient storage in this plants then become important factors in sustaining further growth under various environmental conditions. In tropical country, where vanilla plants are generally planted, there are two main environmental conditions that could affect growth, i.e. wet and dry season. High nutrient uptake during high growth rate in wet season could make a large nutrient pools in the plant until the commencement of dry seasons. Subsequently, when plants growth in the ensuing dry season then decreased because of down regulations, those large nutrient pools are most likely not synthesized into organic compounds. Desiccation of plants because of dry air and high temperature, during dry seasons, will increase concentration of the previously stored nutrient (Chaves 1991).

This high concentration subsequently decrease water potential in leaves and squeeze water from photosynthetic cells which inhibit enzymes activity and impair sugar biosynthesis (Chaves 1991, Adiputra 2014).

Implying that under condition of prolonged drought after a heavy wet season, epiphytes plants such as vanilla and phalaenopsis is becoming more sensitive to fertilizer and endanger its growth. This report describes experiments that examined the effect of fertilizer applications on sugar biosynthesis in vanilla plants and phalaenopsis seedlings.

\section{MATERIAL AND METHODS}

\section{Experiment 1}

Vanilla previously grown for ca 5 years were divided randomly into 4 groups and each group was separately added 9.25, 1.1 and 4.6 g/plant Urea, TSP and KCL respectively. The other group were not added fertilizer as control plants. Shoot tip of these plants ca 3 leaves from the apex were then harvested 3 times, just after the application of fertilizer (To), eleven day after the application (T1) and 24 days after the application (T2). Sugar in this plant materials were extracted using modified methods by Foley et al. 1992 and sugar content in the $\mathrm{mL}$ extract were analyzed spectrophotometrically using Nelson-Somogie methods. This experiment was repeated using different plants with application of fertilizer in higher doses; 18.5, 2.2 and $9.2 \mathrm{~g} /$ plant for Urea, TSP and $\mathrm{KCl}$, respectively.

\section{Experiment 2}

Bottled phalaenopsis seedlings were purchased from orchid shops in Denpasar. Seedlings were collected from this bottle by gently breaking the bottle after it previously wrapped with paper. Culture medium remain attached on the root of these seedlings were washed with tap water. The seedlings were then planted in transparent plastic pots containing moss growth mediums. One seedling was planted per pot and a total of 90 pots were used in this experiment which was divided into 9 batches. These plants were then sprayed with liquinox and rosasoll-N fertilizer with 3 different doses, $o$, half strength and full strength. These plants were sprayed with the fertilizers every 1-2 days for 132 days before its leaves were harvested for examination of sugar content. Sugar from this plants were extracted using modified methods by Foley et al. 1992 and sugar content was analysed using Anthron methods.

\section{RESULTS}

\section{Experiment 1}

Vanilla plants grown in plantation were showing different sugar biosynthesis after addition of fertilizer (Table 1). At the time just after the application of fertilizer, leaves of vanilla plants did not show higher sugar content when added higher doses of fertilizer, except plant added KCL. In the stem, a slight increase of sugar content was found in plant added TSP and KCL. However, at day 11, except control, all plants added higher doses of fertilizer were showing higher sugar content. The highest sugar content was found in 
plants added $9.2 \mathrm{~g} \mathrm{KCL} /$ plant. At day 24, all plant added higher doses of fertilizer were also showing higher sugar content. Interestingly, at day 24, plant added higher doses of fertilizer was showing much higher sugar content relative to that found in day 11. At day 24, the highest sugar content was found in plants added $2.2 \mathrm{~g}$ TSP/plant.

Table 1. Sucrose concentration $(\mathrm{mg} / 100 \mathrm{~mL})$ in shoot tip of vanilla plants sampled after the addition of fertilizer

\begin{tabular}{|c|c|c|c|c|c|c|c|c|c|}
\hline \multirow{3}{*}{$\begin{array}{c}\text { Harvest } \\
\text { Time (Days) }\end{array}$} & \multirow{3}{*}{ Plant parts } & \multicolumn{8}{|c|}{ Fertilizer (g/plant) } \\
\hline & & \multicolumn{2}{|c|}{ Control } & \multicolumn{2}{|c|}{ Urea } & \multicolumn{2}{|c|}{ TSP } & \multicolumn{2}{|c|}{$\mathrm{KCl}$} \\
\hline & & o & $\mathrm{O}$ & 9.25 & 18.5 & 1.1 & 2.2 & 4.6 & 9.2 \\
\hline \multirow[t]{2}{*}{ o } & Leaves & 60.891 & $35 \cdot 385$ & 38.001 & 25.575 & 42.252 & 64.161 & 12.495 & 42.252 \\
\hline & Stem & $73 \cdot 317$ & 56.313 & 55.005 & 43.887 & 98.823 & $54 \cdot 351$ & 61.218 & 118.77 \\
\hline \multirow[t]{2}{*}{11} & Leaves & 65.142 & 96.207 & 26.229 & 52.062 & 16.746 & 36.366 & 8.898 & 12.168 \\
\hline & Stem & 58.929 & 57.948 & 66.123 & 98.169 & 9.879 & 89.013 & 90.648 & 144.93 \\
\hline \multirow[t]{2}{*}{24} & Leaves & 19.362 & 20.016 & 25.575 & 66.45 & 10.533 & 29.172 & 20.343 & 79.53 \\
\hline & Stem & 26.883 & 49.773 & 27.21 & 148.854 & 11.514 & 369.252 & 78.876 & 284.886 \\
\hline
\end{tabular}

\section{Experiment 2}

Fertilizer added to phalaenopsis seeding after transplantation into ex vitro environment was not found to increase sugar content (Table 2). Sugar content found in control plants, which was grown without addition of fertilizer, was the highest, i.e. 0.75 $\mathrm{mg} / \mathrm{g} \mathrm{FW}$. Sugar content was then decreased into 0.16 in plants added $2.5 \mathrm{~mL} / \mathrm{L}$ liquinox and subsequent decreased was found when full strength $(5 \mathrm{~mL} / \mathrm{L})$ of liquinox was added. Relative to control plants, addition of $2.5 \mathrm{~g} / \mathrm{L}$ Rosasol-N also decreased sugar content into $0.21 \mathrm{mg} / \mathrm{g}$ FW. Subsequent decreased was also found when these plants were added higher doses of Rosasol$\mathrm{N}$. In this plant, sugar content was only $0.02 \mathrm{mg} / \mathrm{g} \mathrm{FW}$. When plants added mixed Liquinox and Rosasol-N in half strength doses, sugar content was decreased into $0.18 \mathrm{mg} / \mathrm{g}$ FW. However, sugar content was not detected when plants added mixed full strength Liquinox and Rosasol-N. At day 162, viability of seedling was found decreasing when plants were added increasing doses of fertilizer (Table 2). All seedlings grown without addition of fertilizer (control) sustain growth but only $50 \%$ viability or less was found in seedling grown with addition of full strength Rosasol-N.

Table 2. Sugar content in leaves of phalaenopsis seedling after sprayed with fertilizer every 1-2 days for 132 days.

\begin{tabular}{|c|c|c|c|c|}
\hline \multirow{2}{*}{ Treatment } & \multicolumn{2}{|c|}{ Fertilizer } & \multirow[b]{2}{*}{$\begin{array}{l}\text { Sugar content } \\
(\mathrm{mg} / \mathrm{g} \text { FW })\end{array}$} & \multirow[b]{2}{*}{$\begin{array}{c}\text { Viability at day } 162 \\
\text { (\%) }\end{array}$} \\
\hline & $\begin{array}{l}\text { Liquinox } \\
\text { (mL/L) }\end{array}$ & $\begin{array}{l}\text { Rosasol-N } \\
(\mathrm{g} / \mathrm{L})\end{array}$ & & \\
\hline $\mathrm{P} 1$ & 0 & 0 & 0.75 & 100 \\
\hline P2 & 2.5 & o & 0.16 & 90 \\
\hline $\mathrm{P}_{3}$ & 5 & o & -0.12 & 80 \\
\hline $\mathrm{P}_{4}$ & O & 1.5 & 0.21 & 80 \\
\hline $\mathrm{P}_{5}$ & 2.5 & 1.5 & 0.18 & 90 \\
\hline P6 & 5 & 1.5 & -0.08 & 70 \\
\hline $\mathrm{P}_{7}$ & 0 & 3 & 0.02 & 40 \\
\hline P8 & 2.5 & 3 & 0.54 & 40 \\
\hline P9 & 5 & 3 & -0.12 & 50 \\
\hline
\end{tabular}

\section{DISCUSSIONS}

Increasing sugar content in vanilla plants after addition of fertilizer indicating that vanilla plant grown in plantation in tropical country is subjected to nutrient pressure. However since prolonged drought could occurred during dry seasons, application of fertilizer into this plants do not without a risk. Plants with shallow root system have been acknowledged as very sensitive to drought and importantly vanilla plantation in Indonesia is generally not equipped with irrigation system. Without irrigation system, prolonged period of drought during dry season could severely decrease water content and make a quick jump of mineral 
concentration in the leaves. Desiccation in leaves then inhibit sugar biosynthesis resemble to inhibition of sugar biosynthesis in phalaenopsis seedling added full strength fertilizer. Although the causes of water loss is different, whilst water loss in phalaenopsis seedling is mainly attributed by thin cuticle layer and water loss in vanilla in plantation is attributed by high temperature and dry air, a quick jump of mineral concentration could endanger growth. Therefore, for sustainability of vanilla plantations, it is proposed that irrigation system which is aimed to continuously keep soil moisture is considered very important in order to stabilize water potential in leaves. This stable water potential then enables plant to maintain sugar biosynthesis and alleviate the negative impact of fertilizer taken up.

In theory, ions taken up via the root system after the application of fertilizer could enhance sugar biosynthesis and plants growth because the increase amount of macromolecules biosynthesis. Nitrogen and sulphur ions reduced into various amino acids which is become important component for the synthesis of macromolecules. Whereas nitrogen containing amino acids is might synthesized into Ribulose bisphosphate carboxylase (rubisco) and chlorophyll, sulphur containing amino acid could then synthesize into protein. In the plants, phosphorus is not reduced but incorporated into macromolecules as ester. ATP and NADPH are both macromolecules containing phosphorus which is plays an important role during the synthesis of glucose. While chlorophyll has widely been known responsible for light energy harvesting system, rubisco is macromolecule responsible for the uptake of $\mathrm{CO}_{2}$ from the atmosphere. Thus, the increasing biosynthesis of those macromolecules enable the plants to synthesis more sugar. For the growth of the plants, sugar synthesized in the leaves then distributed into various plants parts. Distribution of this photosynthate involves sodium and potassium ions for pumping sugar across plasma membrane. This kind of membrane transport is mainly occurred during phloem loading in the leaves and phloem unloading in the sink organs. Even though, evidence found in vanilla was not in agreement with that found in phalaenopsis.

In vanilla plants, addition of fertilizer enhanced sugar biosynthesis almost in all plants added fertilizer. By contrast, addition of fertilizers was found inhibit sugar biosynthesis almost in all phalaenopsis seedlings added fertilizer. This evidences is therefore indicates that vanilla plant and phalaenopsis has different feeding characteristics. Assuming that phalaenopsis is a moderate feeder as proposed by Ying Tung Wang et al. (2007), vanilla plants could then be proposed as higher feeders. In both plants however, sufficient water supply seem to be more important than fertilizer additions.

\section{CONCLUSION}

Sugar biosynthesis in epiphyte plants are sensitive to leaf water content which affected by soil moisture and water transpiration via the leaves. Since addition of inorganic nutrient could change water potential in the leaves and affected the amount of water available for physiological mechanism, the effectiveness of fertilizer application is therefore depending not only on watering but also on the capability of plants to maintain sufficient water potential in the leaves. For vanilla plants in plantation, addition of fertilizer in higher doses (18.5, 2.2 and 9.2 g/plant for Urea, TSP and $\mathrm{KCl}$, respectively) increased sugar content. However, sugar biosynthesis was found decreased in all phalaenopsis seedlings added fertilizers. These studies concluded that fertilizer application enhance sugar biosynthesis under condition of sufficient water potential, but impair the synthesis when the leaves undergoing desiccation.

\section{ACKNOWLEDGEMENTS}

This reaseach was funded by Indonesian Direktorate General of Higher Education, Department of Education and Culture, Republic of Indonesia.

\section{REFERENCES}

Adiputra, I.G.K. 2014. Effect of Liquinox and Rosasol$\mathrm{N}$ fertilizers on vegetative growth of phalaenopsis seedlings after transplantation into ex vitro conditions. Aust. J. of Crop Sci. 8(6):951-956.

Anandaraj, M.J. Rema, B. Sasikumar, R. Suseela Bhai. 2005. Vanilla (Extension Pamphlet). V.A. Parthasarathy, Director, Indian Institute of Spices Research.

Chaves, M.M. 1991. Effects of water deficits on carbon assimilation. J.of Exp. Bot. 42(234):1-16.

Foley, M.E., M.O. Bancal and M.B. Nichols. 1992. Carbohydrate status in dormant and afterrippened excised wild oat embryos. Physiol. Plant. 85:461466.

Hernandez, J.H. 2011. Mexican vanilla production. In Handbook of Vanilla science and Technology (D.H. Frenkel and F. Belanger (Eds). Wiley- Blackwell, West Sussex, UK.

Reinert, F. 1998. Epiphytes: photosynthesis, water balance and nutrients. In Scarano (F.R. and A.C. Franco (Eds). Ecophysiological strategies of xerophytic and amphibious plants in the neotropics. Series Oecologia Brasilliensis IV: 87-108.

Yin-Tung Wang, M. Blanchard, R. Lopez, E. Runkle. 2007. Growing the best phalaenopsis. Part 2. Media, tranplating, water and nutrient requirements. www.aos.org.

Zotz, G. and P. Hietz. 2001. The physiological ecology of vascular epiphytes: current knowledge, open questions. J. of Exp. Bot. 52(364):2067-2078. 